\title{
Rainy Season and Its Variability for Crop Planning in Aurad (Bidar Dist.) Region of Karnataka, India
}

\author{
S. Ravi $^{1}$, S.N. Bhat ${ }^{1}$, Kamble Anand Shankar ${ }^{2 *}$ and Vishswanath Biradar ${ }^{2}$ \\ ${ }^{1}$ Department of Soil Science and Agricultural Chemistry, ICAR-KVK, Bidar, \\ UAS, Raichur, Karnataka, India \\ ${ }^{2}$ Department of Agronomy, ICAR-KVK, Bidar, UAS, Raichur, Karnataka, India \\ *Corresponding author
}

\begin{tabular}{|c|c|}
\hline \multicolumn{2}{|r|}{ A B S T R A C T } \\
\hline & \multirow{5}{*}{$\begin{array}{l}\text { Rainfall data for the period } 1957-2015 \text { is used to analyze nakshatra-wise, monthly, } \\
\text { seasonal and annual variability of rainfall. The analysis of daily rainfall data }(1957-2015) \\
\text { indicates that the average annual rainfall for the Aurad region will be } 830.5 \mathrm{~mm} \text {. The } \\
\text { lowest and highest recorded annual rainfall was } 280.4 \text { and } 1337.7 \mathrm{~mm} \text { respectively. The } \\
\text { annual rainfall at Aurad region was distributed as } 660.2 \mathrm{~mm}, 101.1 \mathrm{~mm}, 59.8 \mathrm{~mm} \text { and } 9.4 \\
\text { mm in monsoon (June- September), post monsoon (October - December), summer (March } \\
\text { - May) and winter (January - February) season respectively. The standard deviation and } \\
\text { coefficient of variation for mean annual rainfall was } 241.8 \mathrm{~mm} \text { and } 29.1 \text { per cent } \\
\text { respectively. The highest mean rainfall of } 201.9 \mathrm{~mm} \text { with coefficient of variation of } 59.4 \\
\text { per cent was highest in August month followed by July (182.2 mm) with coefficient of } \\
\text { variation of } 62.5 \text { per cent. However the lowest coefficient of variation of } 58.4 \text { per cent was } \\
\text { noticed during June month with mean rainfall of } 122.5 \mathrm{~mm} \text { indicating lesser variability. } \\
\text { Among the nakshatras Makha nakshatra has recorded the highest mean rainfall of } 98.6 \\
\text { mm and the lowest rainfall (13.6 mm) was from Swati nakshatra. The coefficient of } \\
\text { variation was highest in (164.4 per cent) Chitta nakshatra while Pushya and Pubbha } \\
\text { nakshatra has recorded the lowest coefficient of variation of } 76.8 \text { per cent. The highest } \\
\text { rainfall of } 378.7 \mathrm{~mm} \text { was recorded by the Makha nakshatra during } 2003 \text { and very lowest } \\
\text { rainfall (113.2 mm) by Swati nakshatra during } 1973 \text {. }\end{array}$} \\
\hline $\begin{array}{l}\text { K e y w o r d s } \\
\text { Rainfall, Rainy days } \\
\text { and seasonal rainfall }\end{array}$ & \\
\hline Article Info & \\
\hline $\begin{array}{l}\text { Accepted: } \\
\text { 15 September } 2017 \\
\text { Available Online: } \\
10 \text { November } 2017\end{array}$ & \\
\hline & \\
\hline
\end{tabular}

\section{Introduction}

India's economy is dependent on the agricultural production, which in turn is dependent on the monsoon rainfall and its distribution. The year to year fluctuation in rainfall as well as the fluctuation within the monsoon season governs the crop growth, development and yield. Even in monsoon months the crops are subjected to moisture stress due to occasional dry spells. Although the rainfall is high, the distribution is erratic making the crop vulnerable even during monsoon. Agriculture, especially in developing countries, is a sector which is vulnerable to risks of various types. Most importantly, weather related risks play a major role in affecting agricultural income. These would include extreme rainfall events which result in floods / droughts, as well as extreme temperature events. Poor and small farmers are especially susceptible to income variability because of weather - related risks to their crops. 
The success or failure of the crops in any year is always viewed with great anxiety as they are closely linked with the behavior of the south west monsoon rains received during June to September. Thus for a rainfed crop, rainfall is the only source of water and thereby any fluctuation in rainfall pattern adversely affect the crop production and it tilts the food security of the country. Water is one of the crucial inputs in crop production and its excess or deficit availability/application adversely influences the yield. Rainfall analysis for crop planning was carried out in different regions of the country as reported by Ahmed et al., (2009) in the Barak valley zone of Assam and Sarma et al., (1996) in the hills zone of Assam. Saha et al., (2004) reported rainfall distribution pattern of Cuttack and its implication in rainfed rice and other crop planning for coastal Orissa. Manorama et al., (2007) reported rainfall analysis and crop planning for the Nilgiris. Jadav et al., (1999) reported rainfall probability analysis for crop planning in scarcity zone of Maharashtra. Mahale and Dhane (2003) reported rainfall analysis for Panvel region.

In this context, a similar attempt was made at Krishi Vigyan Kendra, Bidar, to analyze the rainfall variability in nakshatra, month, season and annual wise for Aurad region of Karnataka state.

There is considerable traditional knowledge of variability of rainfall patterns, since rainfed cultivation has been carried out for several centuries in India. The periods used by the farmer are however, not weeks or months but so-called 'nakshatras', which are 13- or 14day periods based on the solar calendar. The nakshatras are constellations through which the sun passes in a year. There are 27 nakshatras; hence the period of each nakshatra is about 13-14 days (Subash et al., 2011).

\section{Materials and Methods}

The daily rainfall data from Agrometeorological Centre, Agricultural Research Station, Bidar years from 1957 to 2015 was used to analyze Nakshatra-wise rainfall distribution for Aurad region. Of the 27 Nakshatras, 12 Nakshatras from Rohini (May 25 to June 7) to Swati (October 24 to November 5) were considered for the analysis. The mean, standard deviation, coefficient of variation (CV\%), minimum and maximum for Nakshatra-wise rainfall were calculated. The rainfall data were critically examined for annual, seasonal and monthly values following the procedure of Panse and Sukhatme (1985). The standard deviation (SD) and coefficient of variance (CV) of rainfall were worked out for the above periods.

\section{Annual rainfall}

The overall mean total annual rainfall of Aurad region for the past fifty eight years (1957-2015) was found to be $830.5 \mathrm{~mm}$ with a coefficient of variation of 29.1 per cent. This revealed that the rainfall was more or less stable over the years. The annual rainfall ranged from 280.4 to $1337.7 \mathrm{~mm}$. The standard deviation for annual rainfall was with mean of $241.8 \mathrm{~mm}$ (Table 2).

\section{Seasonal rainfall}

The average seasonal rainfall and its variability during the seasons winter (January - February), summer (March- May), Monsoon (June - September) and Post monsoon (October - December) are presented in Table 2 and Figure 2. The highest rainfall was received during monsoon season (660.2 $\mathrm{mm})$ followed by post monsoon season (101.1 $\mathrm{mm}$ ) and the lowest by winter season (9.4 $\mathrm{mm}$ ) (Fig. 1). The per cent contribution of seasonal rainfall to the total annual rainfall 
was $79.5,12.2,7.2$ and 1.1 by monsoon, post monsoon, summer and winter seasons respectively with the lowest $\mathrm{CV}$ during monsoon $(33 \%)$, followed by post monsoon
(72\%) and summer (83\%) seasons. As Aurad region is highly benefited through southwest monsoon rainfall, the $\mathrm{CV}$ of the mean rainfall during monsoon season is the lowest.

Table.1 Monthly mean, highest and lowest rainfall along with SD and CV as observed at Aurad (1957-2015)

\begin{tabular}{|l|c|c|c|c|c|c|}
\hline Month & $\begin{array}{c}\text { Lowest } \\
(\mathbf{m m})\end{array}$ & $\begin{array}{c}\text { Highest } \\
(\mathbf{m m})\end{array}$ & $\begin{array}{c}\text { Mean } \\
(\mathbf{m m})\end{array}$ & $\begin{array}{c}\text { SD } \\
\mathbf{m m}\end{array}$ & $\begin{array}{c}\text { CV } \\
(\boldsymbol{\%})\end{array}$ & \% of annual \\
\hline January & 0.0 & 75.8 & 5.6 & 13.5 & 242.6 & 0.7 \\
\hline February & 0.0 & 40.6 & 3.8 & 8.5 & 222.4 & 0.5 \\
\hline March & 0.0 & 73.8 & 11.5 & 20.8 & 180.9 & 1.4 \\
\hline April & 0.0 & 115.5 & 17.8 & 21.8 & 122.6 & 2.1 \\
\hline May & 0.0 & 198.5 & 30.5 & 39.9 & 130.9 & 3.7 \\
\hline June & 11.4 & 386.9 & 122.5 & 71.5 & 58.4 & 14.8 \\
\hline July & 0.0 & 492.1 & 182.2 & 113.9 & 62.5 & 21.9 \\
\hline August & 0.0 & 498.7 & 201.9 & 119.9 & 59.4 & 24.3 \\
\hline September & 0.0 & 427.0 & 153.6 & 99.2 & 64.6 & 18.5 \\
\hline October & 0.0 & 250.6 & 77.0 & 70.9 & 92.0 & 9.3 \\
\hline November & 0.0 & 161.0 & 18.7 & 30.6 & 164.0 & 2.2 \\
\hline December & 0.0 & 58.0 & 5.4 & 12.6 & 232.3 & 0.7 \\
\hline
\end{tabular}

Table.2 Characteristics of annual and seasonal rainfall as observed at Aurad (1957-2015)

\begin{tabular}{|l|c|c|c|c|c|c|}
\hline \multicolumn{1}{|c|}{$\begin{array}{c}\text { Year } / \\
\text { Seasons }\end{array}$} & $\begin{array}{c}\text { Lowest } \\
(\mathbf{m m})\end{array}$ & $\begin{array}{c}\text { Highest } \\
(\mathbf{m m})\end{array}$ & $\begin{array}{c}\text { Mean } \\
\mathbf{( m m )}\end{array}$ & $\begin{array}{c}\text { SD } \\
\mathbf{m m}\end{array}$ & $\begin{array}{c}\text { CV } \\
(\boldsymbol{\%})\end{array}$ & $\begin{array}{c}\text { \% of annual } \\
\text { rainfall }\end{array}$ \\
\hline Annual & 280.4 & 1337.7 & 830.5 & 241.8 & 29.1 & 100.0 \\
\hline Winter & 0.0 & 75.8 & 9.4 & 17.0 & 181.1 & 1.1 \\
\hline $\begin{array}{l}\text { Summer / } \\
\text { Pre-monsoon }\end{array}$ & 0.0 & 198.5 & 59.8 & 50.0 & 83.6 & 7.2 \\
\hline Monsoon & 90.0 & 1210.5 & 660.2 & 222.9 & 33.8 & 79.5 \\
\hline Post monsoon & 0.0 & 279.2 & 101.1 & 73.2 & 72.4 & 12.2 \\
\hline
\end{tabular}

Annual: January - December Winter: January - February Summer: March- May

Monsoon: June - September Post monsoon: October - December

SD: Standard Deviation CV: Coefficient of variation 
Table.3 Statistical characteristics of nakshatra-wise rainfall in Aurad

\begin{tabular}{|l|l|c|c|c|c|c|c|}
\hline \multirow{2}{*}{ Season } & \multirow{2}{*}{ Nakshatra } & \multirow{2}{*}{ Period } & \multicolumn{3}{|c|}{ Rainfall } & Highest rainfall \\
\cline { 4 - 8 } & & & $\begin{array}{c}\text { Mean } \\
(\mathbf{m m})\end{array}$ & $\begin{array}{c}\text { SD } \\
(\mathbf{m m})\end{array}$ & $\begin{array}{c}\text { CV } \\
(\mathbf{\%})\end{array}$ & $\begin{array}{c}\text { Amount } \\
(\mathbf{m m})\end{array}$ & Year \\
\hline Pre-monsoon & Rohini & May 25-Jun.7 & 29.1 & 33.4 & 114.5 & 152.4 & 1960 \\
\hline & Mrigashira & Jun.8-Jun.21 & 58.5 & 50.4 & 86.2 & 210.4 & 1992 \\
\hline Monsoon & Aridhra & Jun.22-Jul.5 & 66.4 & 45.2 & 68.0 & 149.4 & 1995 \\
\hline & Punarvasu & Jul.6-Jul.19 & 79.3 & 71.7 & 90.5 & 309.0 & 1965 \\
\hline & Pushya & Jul.20-Aug.2 & 93.7 & 72.1 & 76.9 & 293.1 & 1989 \\
\hline & Ashlesha & Aug.3-Aug.16 & 86.8 & 76.8 & 88.5 & 358.0 & 1990 \\
\hline & Magha & Aug.17-Aug.30 & 98.6 & 97.8 & 99.2 & 378.7 & 2003 \\
\hline & Purva & Aug.31-Sept.12 & 75.3 & 57.9 & 76.9 & 189.2 & 1998 \\
\hline & Uttara & Sept.13-Sept.26 & 77.1 & 62.8 & 81.4 & 232.4 & 1983 \\
\hline Post-monsoon & Hasta & Sept.27-Oct.10 & 50.1 & 51.0 & 101.7 & 213.7 & 2012 \\
\hline & Chitta & Oct.11-Oct.23 & 29.5 & 48.5 & 164.4 & 207.8 & 1974 \\
\hline & Swati & Oct.24-Nov.5 & 13.6 & 22.0 & 161.6 & 113.2 & 1973 \\
\hline
\end{tabular}

Fig.1 Monthly average rainfall (mm) as recorded at Aurad

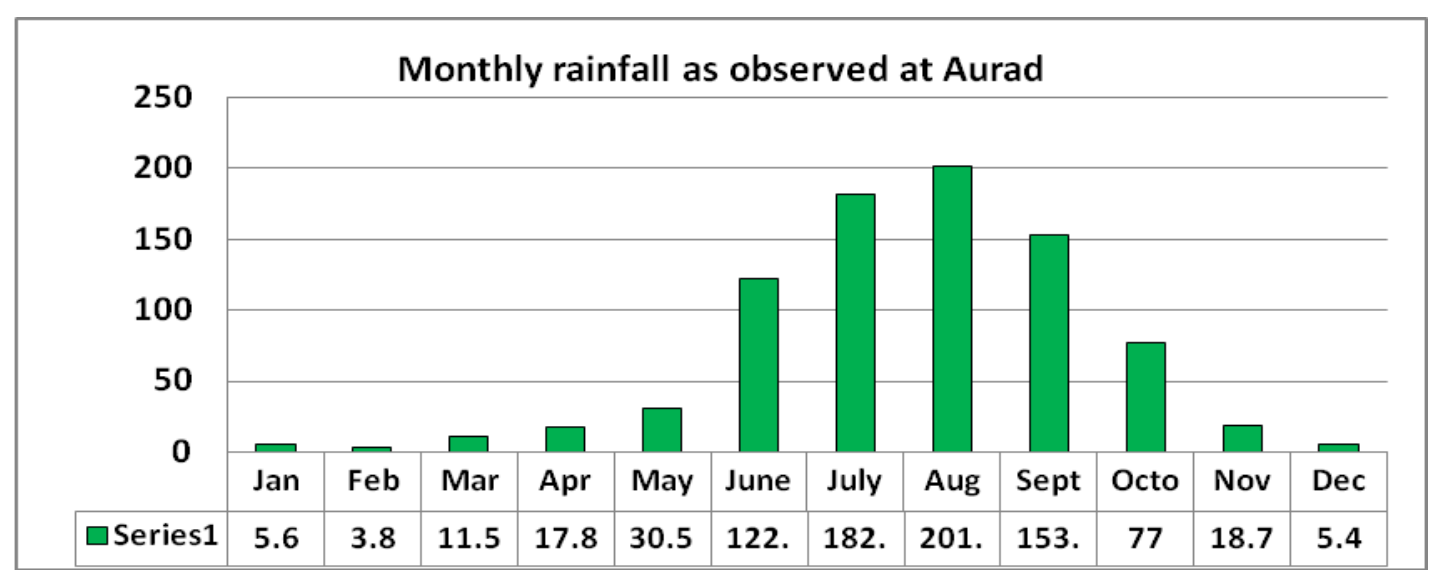

Fig.2 Average season wise rainfall $(\mathrm{mm})$ as observed at Aurad

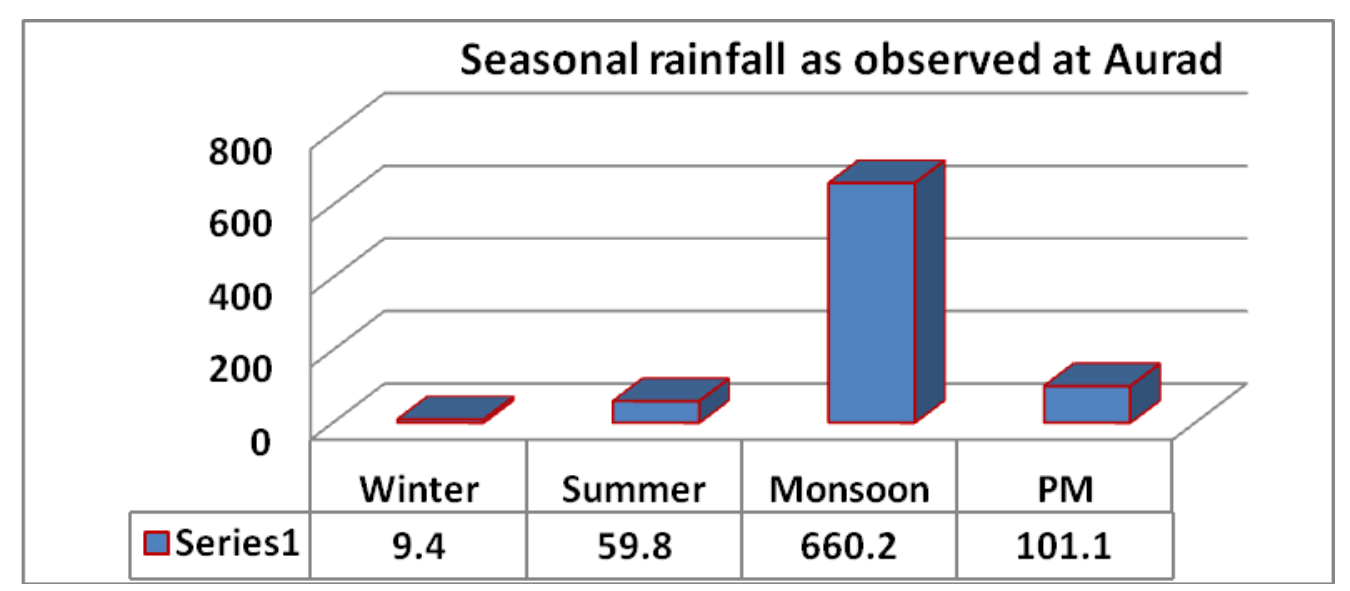




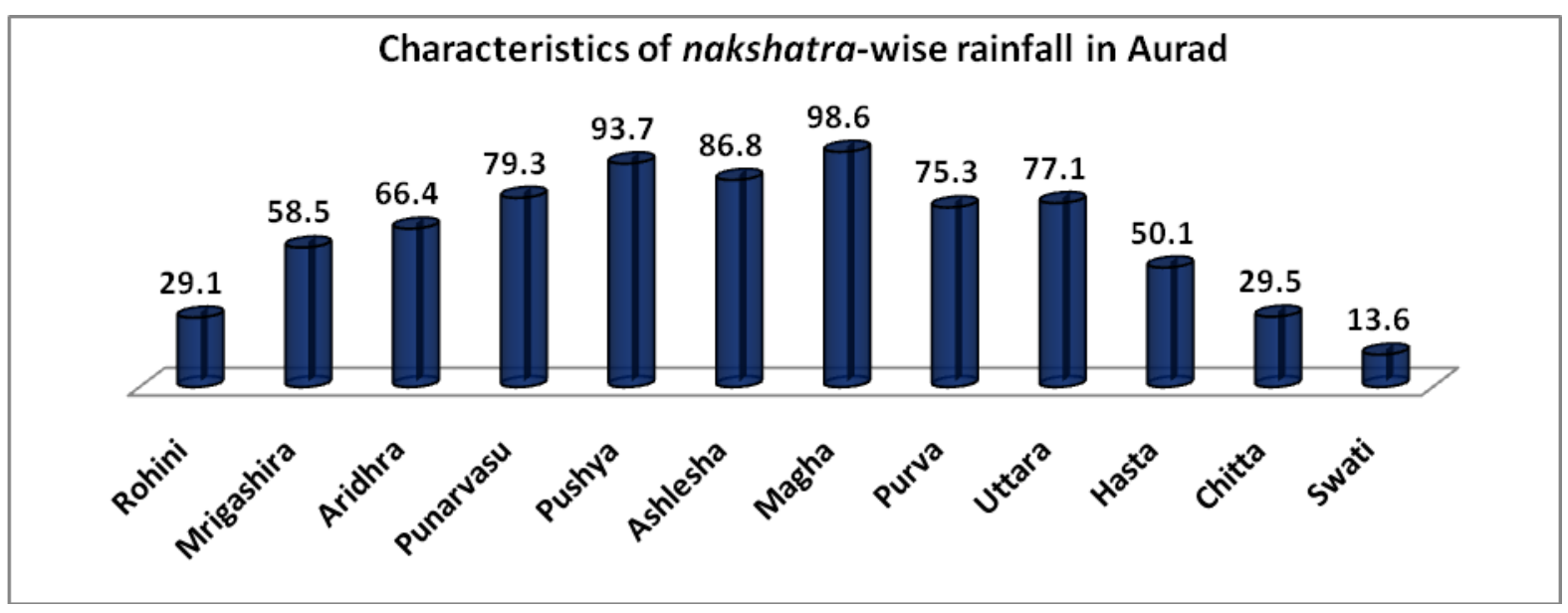

\section{Monthly rainfall}

From Table 1, it could be observed that rainfall in this region increases from April month onwards, attains a peak during August and then falls down reaching the lowest value of $3.8 \mathrm{~mm}$ during February month. Mean monthly rainfall is highest in August (201.9 $\mathrm{mm}$ ) with its contribution of 24.3 per cent to the total annual rainfall. It is observed that there is higher dependability of rainfall from the month of June to October (CV 58 - $92 \%$ ). Hence, a successful cultivation of pigeon pea based cropping system under rainfed condition with medium or long duration varieties is possible during that period.

The highest rainfall during Nakshatra periods are presented in Table 3. The rainfall during Nakshatra periods ranged from $149.4 \mathrm{~mm}$ to $378.7 \mathrm{~mm}$. Magha Nakshatra received the highest rainfall of $378.7 \mathrm{~mm}$ during 2003 followed by Ashlesha Nakshatra of 358.0 $\mathrm{mm}$. The lowest rainfall of $149.4 \mathrm{~mm}$ was recorded for Aridhra during 1995.

The average rainfall during monsoon season $(660.2 \mathrm{~mm})$ with its highest contribution of 79.5 per cent to the total annual rainfall revealed that during the season, a major part of rainfall amount is generally lost through runoff which can be stored through water harvesting structures such as farm ponds and lakes and used during the winter season for growing rabi crops. Also it can be utilized as life saving irrigation particularly in years of low rainfall. During post monsoon season, which contributes to 12.2 per cent of the total annual rainfall, an average amount of 101.1 $\mathrm{mm}$ rainfall could satisfy the cultivation of less water requiring crops such as pulses (Chickpea), sunflower, safflower crops. About 7.2 per cent of total annual rainfall received during summer season (March-May) would be helpful for land preparation particularly for summer ploughing operation during the season.

\section{References}

Ahmed P., Deka, R. L., Baruah, B. P. and Nath, K. K. (2009). Rainfall based crop planning in the Barak Valley zone of Assam. J. Agrometeorol., 11(2): 192195.

Jadav et al., (1999) reported rainfall probability analysis for crop planning in scarcity zone of Maharashtra. $J$. Agrometeorol., 1(1): 59-64.

Mahale, D. and Dhane, S. S. (2003). Rainfall analysis in relation to paddy crop in coastal saline soils of Panvel. $J$. Agrometeorol., 5(1): 89-92.

Manorama, K., Ravichandran, G. and Joseph, T. A. (2007). Rainfall analysis and crop planning for the Nilgiris. $J$. 
Agrometeorol., 9(2): 209-215.

Panes, R. S and Sukhatme, P. V. (1985). Statistical methods for agriculture workers. Indian Council of Agricultural Research, New Delhi. 14-33.

Saha, S., Biswal, G. C. and Singh, B. N. (2004). Rainfall distribution pattern of Cuttack and its implication in rainfed rice and other crop planning for coastal Orissa. J. Agrometeorol., 6(1): 92-97.

Sarma, N. N., Paul, S. R. and Sarma, D.
(1996). Rainfall pattern and rainfall based cropping system for the hill zone of Assam. Ann. of Agric. Res., 17: 223229.

Subash, N., Singh, S.S., and Neha Priya., 2011. Nakshatra based rainfall variability, trends and its influences on rice wheat production- A case study over two cities in Bihar, India. Journal of Agrometeorology, 13(1): 31-37.

\section{How to cite this article:}

Ravi, S., S.N. Bhat, Kamble Anand Shankar and Vishswanath Biradar. 2017. Rainy Season and Its Variability for Crop Planning in Aurad (Bidar Dist.) Region of Karnataka. Int.J.Curr.Microbiol.App.Sci. 6(11): 1856-1861. doi: https://doi.org/10.20546/ijcmas.2017.611.221 